\title{
PENENTUAN BESAR CADANGAN PADA ASURANSI JIWA BERSAMA DWIGUNA DENGAN MENGGUNAKAN METODE ILLINOIS
}

\author{
FERDY NOVRI \\ Program Studi Matematika, \\ Fakultas Matematika dan Ilmu Pengetahuan Alam, Universitas Andalas, \\ Kampus UNAND, Limau Manis Padang, Indonesia, \\ email :ferdynovri@ymail.com
}

\begin{abstract}
Abstrak. Asuransi jiwa merupakan suatu upaya yang dilakukan oleh manusia untuk mengurangi dampak kerugian dari suatu peristiwa yang tidak dapat diprediksi. Asuransi jiwa berdasarkan jumlah tertanggungnya dibedakan menjadi asuransi jiwa perorangan yang memberikan perlindungan untuk satu orang dan asuransi jiwa bersama yang memberikan perlindungan lebih dari satu orang. Pada saat tertentu perusahaan bisa saja mengalami kerugian ketika terdapat tertanggung yang meninggal dunia tetapi perusahaan tidak mempunyai dana, sedangkan perusahaan tersebut harus mengeluarkan sejumlah dana untuk santunan. Oleh karena itu, untuk mengantisapasi kerugian perusahaan, maka sebagian dari premi yang diterima oleh perusahaan harus dicadangkan sebagai cadangan premi, sehingga bila dimasa yang akan datang terjadi klaim maka perusahaan tidak kesulitan membayarnya. Penelitian ini bertujuan untuk menentukan besarnya cadangan yang diperoleh dengan menggunakan metode Illinois yang merupakan perluasan dari cadangan prospektif. Metode Illinois adalah metode perhitungan cadangan berdasarkan premi yang disesuaikan dengan batasan 20 tahun pembayaran, sehingga besarnya cadangan yang dihasilkan lebih besar daripada metode cadangan lainnya.
\end{abstract}

Kata Kunci: Asuransi jiwa bersama dwiguna, cadangan premi, cadangan prospektif, metode Illinois

\section{Pendahuluan}

Sebuah perlindungan tentu dibutuhkan oleh setiap orang, banyak cara yang dapat dilakukan baik untuk melindungi diri, keluarga dan harta benda miliknya. Pada zaman sekarang perlindungan akan jaminan hidup sangat dibutuhkan, terutama tentang meminimalisir kerugian dalam hidup tersebut. Meminimalisir kerugian dalam hidup itu bisa diatasi dengan asuransi.

Salah satu bentuk perusahaan asuransi adalah asuransi jiwa. Asuransi jiwa yang berkembang di Indonesia ada dua macam, yaitu asuransi jiwa tunggal dan asuransi jiwa bersama. Perbedaan antara asuransi jiwa tunggal dengan asuransi jiwa bersama terletak pada jumlah tertanggungnya. Kebanyakan dari peserta asuransi memilih asuransi bersama karena tingginya santunan yang diinginkan berbanding lurus dengan harga polis asuransi yang sangat mahal, maka dari itu untuk memenuhi pembayaran premi yang mahal tersebut dibentuklah asuransi bersama.

Pada asuransi jiwa, untuk dapat membayarkan santunan kepada tertanggung atau pemegang polis saat terjadi klaim, perusahaan asuransi atau penanggung 
harus mempunyai dana dari premi yang dibayarkan tertanggung. Dana yang dihimpun dari premi yang diperoleh dari pemegang polis sebagai kewajiban perusahaan asuransi terhadap pemegang polis di masa mendatang tersebut dikatakan sebagai cadangan premi [3]. Perhitungan cadangan premi dapat digunakan dalam berbagai bentuk metode perhitungan. Namun dari semua metode, cadangan Illinois adalah cadangan yang lebih baik digunakan karena dapat membatasi biaya yang dibebankan perusahaan asuransi kepada peserta asuransi pada pembayaran premi tahunan, dengan batasan cadangan maksimal 20 tahun pembayaran, sehingga besarnya cadangan yang dihasilkan lebih besar daripada cadangan yang lainnya [7]. Untuk itu, dalam penelitian ini penulis akan menentukan besarnya cadangan pada asuransi jiwa bersama dengan menggunakan metode Illinois.

\section{Penentuan Model Cadangan dengan Metode Illinois pada Asuransi Jiwa Bersama (Joint Life Insurance) Dwiguna}

Perusahaan asuransi memerlukan sumber dana tambahan dalam menjalankan tugasnya untuk menutup biaya awal tahun. Dana tersebut dapat diperoleh dengan menyesuaikan cadangan premi (cadangan disesuaikan) yang dianggap berupa pinjaman dan akan dibayar kemudian dari pembayaran premi kotor di tahun-tahun mendatang.

Misalkan $P$ menyatakan premi bersih untuk suatu jenis asuransi. Untuk melakukan perhitungan cadangan dengan menggunakan metode Illinois premi tersebut dinyatakan dengan $\alpha$ pada tahun pertama dan diikuti oleh $\beta$ pada tahuntahun berikutnya. Nilai premi $\alpha$ dan $\beta$ hanya ada dalam perhitungan aktuaria dan tidak ada hubungannya dengan pemegang polis. Nilai $P, \alpha$ dan $\beta$ dihubungkan oleh

Nilai sekarang seluruh $P=$ Nilai sekarang $\alpha+$ Nilai sekarang seluruh $\beta$

Persamaan ini berlaku pada waktu polis dikeluarkan. Bila $n$ menyatakan jangka waktu penyesuaian cadangan, maka hubungan pada persamaan tersebut dapat didefinisikan sebagai berikut:

$$
\alpha+\beta \alpha_{x y: \overline{n-1 \mid}}=P \ddot{a}_{x y: \bar{n} \mid},
$$

dimana $\alpha<P$, karena sebagian dari $P$ dipakai untuk biaya tahun pertama, yaitu sebesar $P-\alpha$. Jadi, dari premi bersih tahun pertama sebesar $P$, hanya $\alpha$ yang disediakan untuk membayar santunan di tahun tesebut, sisanya $P-\alpha$ dipinjam perusahaan dan pinjaman tersebut akan dibayar kelak dari premi-premi tahun berikutnya. Karena itu $\beta>P$, jadi $\alpha<P<\beta$. Berdasarkan uraian tersebut dibutuhkan suatu metode perhitungan untuk menentukan besarnya cadangan asuransi yang disesuaikan dengan menggunaan metode Illinois.

Metode cadangan Illinois adalah metode perhitungan cadangan yang disesuaikan berdasarkan premi yang disesuaikan dengan batasan 20 tahun pembayaran. Pada metode Illinois terdapat tiga nilai premi bersih yaitu:

(1) $\alpha^{I}$ (premi bersih pada tahun pertama)

(2) $\beta^{I}$ (premi bersih untuk 19 tahun berikutnya)

(3) $P$ (premi bersih tahunan). 
Premi bersih modifikasi pada metode cadangan Illinois dapat dinyatakan sebagai berikut:

$$
\beta^{I}-\alpha^{I}={ }_{19} P_{x+1, y+1}-\frac{C_{x y}}{D_{x y}},
$$

dimana $\frac{C_{x y}}{D_{x y}}$ premi berjangka satu tahun yang diperpanjang setiap tahunnya sampai waktu tertentu dan premi tahunan tidak boleh melebihi premi bersih tahunan pada asuransi jiwa seumur hidup dengan masa pembayaran 19 tahun pada saat usia satu tahun lebih tinggi dari usia kebijakan tersebut $\left({ }_{19} P_{x+1, y+1}\right)$. Sehingga persamaan (2.2) dapat dituliskan kembali menjadi

$$
\alpha^{I}=\beta^{I}-\left({ }_{19} P_{x+1, y+1}-\frac{C_{x y}}{D_{x y}}\right) .
$$

Persamaan umum metode Illinois untuk polis dengn pembayaran premi $>20$ tahun, dapat dituliskan sebagai berikut.

$$
\alpha^{I}+\beta^{I} \alpha \overline{x, y: 19 \mid}+P_{20 \mid n-20} \ddot{a}_{x, y}=P \ddot{a}_{\overline{x, y: n \mid}},
$$

karena $\ddot{a}_{\overline{x, y: n \mid}}=\ddot{a}_{\overline{x, y: 20 \mid}}+{ }_{20 \mid n-20} \ddot{a}_{x, y}$,

maka persamaan (2.4) dapat dinyatakan menjadi

$$
\alpha^{I}+\beta^{I} a \overline{x, y: 19 \mid}=P \ddot{a} \overline{x, y: 20 \mid} .
$$

Persamaan umum metode Illinois untuk polis dengan pembayaran premi $\leq 20$ tahun, maka dapat dituliskan sebagai berikut:

$$
\begin{aligned}
& \alpha^{I}+\beta^{I} a_{\overline{x, y: k-1 \mid}}=P \ddot{a}_{\overline{x, y: k \mid}}, \\
& \beta^{I}=P+\frac{19 P_{x+1, y+1}-\frac{C_{x, y}}{D_{x, y}}}{\ddot{a}_{\overline{x, y: k \mid}}},
\end{aligned}
$$

dengan $k$ adalah nilai terkecil dari $n$ dan 20. $n$ adalah jangka waktu pembayaran premi dan nilai $\beta^{I}$ dapat digunakan untuk perhitungan cadangan dengan menggunakan metode prospektif. Cadangan Illinois dinotasikan sebagai ${ }_{t}^{m} V^{(I)}{ }_{x y: \bar{n} \mid}$ dan selanjutnya $\beta^{I}$ dinotasikan sebagai premi tahunan. Sehingga untuk besarnya cadangan dari tahun ke $t$ sampai ke $n$ adalah

$$
\begin{aligned}
& { }_{t}^{m} V_{x y: \overline{n \mid}}^{(I)}=A_{x+t, y+t: \overline{n-t \mid}}-\beta \ddot{a}_{x+t, y+t: \overline{20-t} \mid}-{ }_{m} P_{x, y: \bar{n} \mid}\left[20-t \mid m-20 \ddot{a}_{x+t, y+t}\right] ; t \leq 20, \\
& { }_{t}^{m} V^{(I)}{ }_{x y: \overline{n \mid}}=A_{x+t, y+t: \overline{n-t \mid}}-{ }_{m} P_{x, y: \overline{n \mid}} \ddot{a}_{x+t, y+t: \overline{m-t \mid}} ; 20<t \leq m, \\
& { }_{t}^{m} V^{(I)}{ }_{x y: \overline{n \mid}}=A_{x+t, y+t: \overline{n-t \mid}} ; m<t \leq n \text {. }
\end{aligned}
$$

\section{Ilustrasi Kasus}

Kehidupan yang dikaitkan dengan terjadinya suatu musibah tidak dapat diramalkan dengan tepat kapan terjadinya. Musibah tersebut dapat berupa penyakit, kecelakaan yang mengakibatkan cacat ataupun kematian. Menyadari hal tersebut, seorang suami berusia 46 tahun hendak mengikuti program status hidup gabungan untuk asuransi bersama (joint life insurance) bersama istrinya yang berusia 40 
tahun dengan lama masa pertanggungan 25 tahun dan jangka waktu pembayaran premi 21 tahun. Premi akan dibayarkan setiap awal tahun selama tertanggung masih hidup dan besar santunan yang akan diterima ahli waris ketika suami atau istrinya meninggal dunia adalah Rp. 200 juta.

Berdasarkan data pada kasus diatas, maka jenis asuransi yang dipilih adalah status hidup gabungan untuk asuransi bersama (joint life insurance) dengan menggunakan tabel Mortalitas Indonesia 1999 dengan suku bunga $i=2,5 \%$.

(i) Usia tertanggung, misalkan $x=46$ tahun dan $y=40$ tahun.

(ii) Lama masa pertanggungan, misalkan $n=25$ tahun.

(iii) Jangka waktu pembayaran premi, misalkan $m=21$ tahun.

(iv) Uang pertanggungan, misalkan $R=\mathrm{Rp} 200$ juta.

(v) Tingkat suku bunga, misalkan $i=0,025$.

Pada kasus ini, sebagaian dari premi harus dicadangkan oleh perusahaan dengan menggunakan metode Illinois, sehingga bila di masa yang akan datang terjadi klaim maka perusahaan tidak kesulitan membayarnya. Besarnya cadangan premi yang dimiliki perusahaan asuransi jiwa dipengaruhi oleh pembayaran premi yang dibayarkan oleh pemegang polis.

(a) Perhitungan premi bersih tahunan asuransi jwa dwiguna yang akan dibayarkan oleh seorang suami berusia 46 tahun dan seorang istri berusia 40 tahun dengan lama masa pertanggungan 25 tahun, masa pembayaran premi 21 tahun adalah

$$
{ }_{m} P_{x, y: \overline{n \mid}}=\operatorname{Rp} 7.896 .078,035 .
$$

(b) Perhitungan nilai sekarang dari santunan pada tahun ke- $t$, pada asuransi jiwa dwiguna untuk kasus seorang suami yang berusia 46 tahun dan seorang istri 40 tahun dengan lama masa pertanggungan 25 tahun adalah

$$
A_{x+t, y+t: \overline{n-t \mid}}=\operatorname{Rp} 121.588 .100,8 .
$$

(c) Perhitungan anuitas selama masa pertanggungan yang dibayarkan setiap awal periode.

(i) Lama masa pertanggungan 25 tahun dan pembayaran premi tiap awal tahun untuk kasus seorang suami yang berusia 46 tahun dan seorang istri 40 tahun dengan lama masa pertanggungan 25 tahun adalah

$$
\ddot{a}_{x, y: \bar{n} \mid}=16,59089007 .
$$

(ii) Lama masa pertanggungan 25 tahun dan jangka waktu pembayaran premi 21 tahun pada asuransi jiwa tiap awal tahun untuk kasus seorang suami yang berusia 46 tahun dan seorang istri 40 tahun adalah

$$
\ddot{a}_{x, y: \overline{m \mid}}=15,07539008 .
$$

(iii) Lama masa pertanggungan 25 tahun dan jangka waktu pembayaran 21 tahun pada asuransi jiwa tiap awal tahun untuk kasus seorang suami yang berusia 46 tahun dan seorang istri 40 tahun maka nilai sekarang 
pembayaran anuitas diwaktu yang akan datang pada cadangan tahun ke- $t$ di akhir tahun pertama adalah

$$
\ddot{a}_{x+t, y+t: \overline{m-t \mid}}=14,5061339 .
$$

(iv) Nilai sekarang untuk pembayaran anuitas diwaktu yang akan datang pada metode cadangan Illinois dengan batasan pembayaran premi 20 tahun yaitu di akhir tahun pertama adalah

$$
\ddot{a}_{x+t, y+t: \overline{20-t \mid}}=14,04648 .
$$

(v) Besarnya cadangan premi dengan menggunakan metode cadangan prospektif di akhir tahun pertama adalah

$$
{ }_{t}^{m} V_{x, y}=\operatorname{Rp} 7046535,7 .
$$

(vi) Perhitungan premi tahunan untuk menentukan cadangan dengan menggunakan metode Illinois adalah

$$
\beta^{I}=\operatorname{Rp} 8.353 .387,013 .
$$

(vii) Besarnya cadangan premi dengan menggunakan metode cadangan Illinois di akhir tahun pertama adalah

$$
{ }_{t}^{m} V_{x, y}^{(I)}=\mathrm{Rp} 622.956,5218 .
$$

Selanjutnya akan diperlihatkan besarnya cadangan premi dengan metode prospektif dan cadangan yang disesuaikan dengan metode Illinois pada asuransi jiwa dwiguna untuk kasus seorang suami yang berusia 46 tahun dan seorang istri 40 tahun dengan lama masa pertanggungan 25 tahun, jangka pembayaran premi 21 tahun pada Tabel 3.

Pada Tabel 3 perhitungan cadangan dengan menggunakan metode prospektif dan metode Illinois nilainya cenderung stabil dari tahun ke tahun. Nilai cadangan yang diperoleh dengan metode prospektif lebih besar daripada metode cadangan Illinois. Hal ini disebabkan karena metode prospektif hanya menggunakan premi bersih tanpa mempertimbangkan biaya operasional. Perhitungan cadangan premi tanpa mempertimbangan biaya operasional dapat mengakibatkan perusahaan asuransi mengalami kerugian karena besarnya cadangan premi yang diperoleh tidak sesuai dengan perhitungan, maka dari itu cadangan Illinois dapat menghindari resiko kerugian tersebut.

Dapat dilihat bahwa pada tahun ke-1 hingga tahun ke-19 nilai cadangan disesuaikan dengan metode Illinois lebih kecil daripada cadangan premi dan pada akhir jangka waktu 20 tahun nilai kedua cadangan adalah sama. Pada akhir tahun jangka waktu polis, nilai cadangan disesuaikan dengan metode Illinois dan nilai cadangan premi sama dengan nilai santunan yang diberikan. Hal ini berarti bahwa pada saat masa pertanggungan asuransi berakhir, perusahaan asuransi telah siap untuk memberikan santunan sebesar yang dijanjikan kepada pemegang polis (tertanggung). 
Tabel 1. Tabel cadangan prospektif dan cadangan yang disesuaikan dengan metode Illinois pada asuransi jiwa dwiguna untuk kasus seorang suami yang berusia 46 tahun dan seorang istri 40 tahun

\begin{tabular}{|c|c|r|r|}
\hline Tahun & Premi Bersih & ${ }_{t}^{m} V_{x, y}$ (Cadangan Prospektif) & ${ }_{t}^{m} V_{x, y}^{(I)}$ (Cadangan Illionis) \\
\hline 1 & 7896078,035 & 7046535,696 & 622956,522 \\
\hline 2 & 7896078,035 & 14186493,220 & 8033592,395 \\
\hline 3 & 7896078,035 & 21419517,610 & 15541474,080 \\
\hline 4 & 7896078,035 & 28752095,870 & 23153393,980 \\
\hline 5 & 7896078,035 & 36193622,720 & 30879157,890 \\
\hline 6 & 7896078,035 & 43763121,360 & 38738521,180 \\
\hline 7 & 7896078,035 & 51478458,640 & 46750051,110 \\
\hline 8 & 7896078,035 & 59358536,700 & 54933390,280 \\
\hline 9 & 7896078,035 & 67411060,880 & 63296645,120 \\
\hline 10 & 7896078,035 & 75637559,410 & 71841583,580 \\
\hline 11 & 7896078,035 & 84036356,050 & 80566720,820 \\
\hline 12 & 7896078,035 & 92601445,120 & 89466188,630 \\
\hline 13 & 7896078,035 & 101339368,700 & 98547135,7500 \\
\hline 14 & 7896078,035 & 110274353,300 & 107835002,500 \\
\hline 15 & 7896078,035 & 119455255,600 & 117380610,400 \\
\hline 16 & 7896078,035 & 128922455,200 & 127226150,800 \\
\hline 17 & 7896078,035 & 138720633,100 & 137418352,700 \\
\hline 18 & 7896078,035 & 148898573,100 & 148008339,700 \\
\hline 19 & 7896078,035 & 159515965,600 & 159058656,600 \\
\hline 20 & 7896078,035 & 170642130,000 & 170642130,000 \\
\hline 21 & 7896078,035 & 182370427,900 & 182370427,900 \\
\hline 22 & & 186233574,300 & 186233574,300 \\
\hline 23 & & 190586584,800 & 190586584,800 \\
\hline 24 & & 195120000,000 & 195120000,000 \\
\hline 25 & & 200000000,000 & 200000000,000 \\
\hline
\end{tabular}

\section{Kesimpulan}

Model cadangan pada asuransi jiwa bersama dwiguna dengan menggunakan metode Illinois dapat ditentukan dengan cara sebagai berikut.

(1) Menentukan besarnya anuitas hidup awal pada tahun ke - $t$, selama masa pertanggungan $n$ tahun untuk tertanggung berusia $x$ dan $y$ tahun.

(2) Menentukan besarnya anuitas hidup awal untuk jangka pertanggungan $m-$ $t$ tahun pada usia $x+t$ dan $y+t$ tahun dengan $0 \leq t \leq n$.

(3) Menentukan premi tunggal pada usia $x$ dan $y$ tahun dengan jangka waktu $n$ tahun.

(4) Menentukan besarnya cadangan premi dengan metode prospektif menggunakan premi tahunan pada usia $x$ dan $y$ tahun dengan jangka waktu $n$ tahun. 
(5) Menentukan model cadangan premi dengan metode Illinois.

\section{Ucapan Terima Kasih}

Penulis mengucapkan terimakasih kepada Bapak/Ibu Dr. Dodi Devianto, Dr. Admi Nazra, Zulakmal, M.Si, Riri Lestari, M.Si, dan Dr. Ferra Yanuar yang telah memberikan masukan dan saran sehingga jurnal ini dapat diselesaikan dengan baik.

\section{Daftar Pustaka}

[1] Aide Revani, Marlia, dkk. 2012. Penentuan Cadangan Disesuaikan pada Asuransi Jiwa Berjangka Berpasangan dengan Metode Illinois. Jurnal Gaussian. I (1): $147-158$

[2] Bain, Lee dan Max Engelhardt. 1991. Introduction to Probability and Mathematical Statistics. Duxbury Press, California

[3] Futami, Takashi. 1993. Matematika Asuransi Jiwa Bagian I. Incorporated Foundation Oriental Life Insurance Cultural Development Center, Tokyo

[4] Futami, Takashi. 1994. Matematika Asuransi Jiwa Bagian II. Incorporated Foundation Oriental Life Insurance Cultural Development Center, Tokyo

[5] Gerber, HU. 1997. Life Insurance Mathematics Third Edition. Swiss Association of Actuaries Zurich: Swiss

[6] Jordan Jr, C.W. 1991. Society of Actuaries Textbook on Life Contingencies. Second Edition. The Society of Actuaries: Chicago

[7] Larson, R., E. A. Gaumnitz. 1951. Life Insurance Mathematics. John Wiley and Sons Inc, New York

[8] Salim, A. 2007. Asuransi dan Manajemen Resiko. Raja Grafindo Pustaka, Jakarta

[9] Sembiring, RK. 1986. Buku Materi Pokok Asuransi I. Karunika Universitas Terbuka, Jakarta

[10] Sitanggang, C., D. Kerami. 2003. Kamus Matematika. Balai Pustaka, Jakarta 